\title{
Karriereforventninger under glasstaket:
}

\section{Kvinner i starten av en ingeniørkarriere}

\author{
Aagoth Elise Storvik og Bente Abrahamsen
}

\begin{abstract}
Abstrakt
Ingeniørutdanningen utgjør en av de viktigste lederutdanningene i Norge. Tidligere forskning viser at innenfor ingeniøryrket har kvinner lavere sannsynlighet for å få lederstillinger enn sine mannlige kolleger. I denne studien undersøkes kvinnelige og mannlige ingeniørstudenters karriereambisjoner og forventinger til fremtidig karriere. Spørsmålet som tas opp, er om kjønnsforskjellene i lederstillinger kan knyttes til kvinner og menns ambisjoner og fremtidige karriereforventninger. Resultatene viser at kvinnelige studenter har minst like høye karriereambisjoner som sine mannlige medstudenter, men oppgir likevel lavere forventninger om lederansvar. Ulike forklaringer på disse funnene diskuteres, og noe overraskende gir analysene ingen empirisk støtte til de vanligste forklaringene på kjønnsforskjeller i karriereutvikling. Kvinnelige og mannlige studenter har like preferanser og kvinnene har ikke lavere selvtillit enn menn. Videre har omsorg for barn lik betydning for kvinner og menn for utvikling av karriereambisjoner og lederforventinger. Det som derimot synes å forklare kvinners lavere forventinger om lederstillinger, er forestillingen om et glasstak. Studien er basert på en spørreskjemaundersøkelse (StudData) blant ingeniørstudenter i deres siste studiesemester.
\end{abstract}

Emneord: Ledelse, kjønn, karriere, ingeniører, forventninger 


\section{Innledning}

Fremdeles er kvinner underrepresentert i lederstillinger, både på lavere og høyere nivå i arbeidslivet. Mest ekstrem er situasjonen på høyeste nivå i næringslivet. I allmennaksjeselskaper er kun 7\% av daglige ledere kvinner (SSB, 2017). Sammen med siviløkonomutdanningen er ingeniørutdanningene svært viktige leverandører av fremtidige ledere i privat sektor (Amdam \& Kvålshaugen, 2016, s. 235). Karlsen (2012b, s.157) har tidligere vist at menn med ingeniørutdanning har større sjanse for å bli leder enn kvinner med tilsvarende utdanning. Samtidig jobber kvinnene oftere i offentlig sektor enn sin mannlige kolleger, og de tjener dårligere (Karlsen, 2012b, s.158).

To hovedtyper av forklaringer har blitt lansert på kvinners underrepresentasjon $\mathrm{i}$ lederstillinger. Den ene hovedtypen av forklaringer, etterspørsels-forklaringer, peker på at kvinner møter flere barrierer i arbeidslivet enn menn, i form av ulike typer diskriminering. Disse barrierene refereres ofte til som glasstaket (U.S. Glass Ceiling Commission, 1995). Den andre hovedtypen av forklaringen, tilbuds-forklaringer, peker på kvinnene selv, deres holdninger, oppfatninger og livssituasjon. I denne artikkelen ser vi først og fremst på sist nevnte hovedtype av forklaring. Vi undersøker eventuelle kjønnsforskjeller i ingeniørstudentenes fremtidige ambisjoner og forventninger og diskuterer om disse kan forklare kvinnenes lavere sannsynlighet for å havne i lederstillinger. Er det slik at kvinner som utdanner seg til ingeniører er mindre ambisiøse og har lavere karriereforventinger enn sine mannlig medstudenter? Vi er spesielt opptatt av forventninger fordi disse fort kan bli til selvoppfyllende profetier. Hvis kvinner i mindre grad forventer å få lederansvar, kan det også føre til at de sjeldnere får lederstillinger. Studien er basert på StudData, en spørreskjemaundersøkelse som omfatter 375 ingeniørstudenter (bachelor-nivå) i siste studiesemester. Undersøkelsen er utført i 2007, som er det siste året med opplysninger om studenter ved ingeniørutdanningen.

\section{Tidligere forskning}

Ingeniøryrkene er svært mannsdominert og det gjelder også, om enn i noe mindre grad, ingeniørstudiene. På tross av ulike tiltak ligger kvinneandelen fremdeles bare på 18\%, i motsetning til økonomi- og administrasjonsfag hvor det var 55\% kvinner på bachelorstudiene 
i 2015 (Arnesen et al., 2015, s.27). Grunnen til at kvinner ikke har inntatt ingeniørstudiene på samme vis som de har inntatt for eksempel økonomistudiene, er antatt å være den sterke assosiasjonen som eksisterer mellom maskulinitet og teknologi i vår kultur (Sappleton \& Takuri-Rizk, 2008, s. 293). Karlsen (2012a) finner at kvinner og menn i ingeniøryrkene jobber innenfor litt ulike grener av faget og i litt ulike stillingstyper. Kvinneandelen blant kjemiingeniører og bioingeniører er klart høyere enn for andre typer ingeniører (Utdanning, 2018). Videre befinner kvinnene seg oftere i stillinger som ikke er primære ingeniørstillinger, dvs. i stillinger som også kan besettes av andre yrkesgrupper (Karlsen, 2012b, s. 157). Denne tendensen er ikke utelukkende et norsk fenomen, også internasjonale studier viser at kvinnelige ingeniører sjeldnere enn mannlige kolleger blir ledere og at de oftere arbeider utenfor kjerneområdet i yrket (Sappleton \& Takuri-Rizk, 2008, s. 286).

Bandura (1997, s. 436) mener det er grunn til å anta at kvinner som søker seg til sterkt mannsdominerte fag og yrker er en selektert gruppe som er preget av mer likestillingsorientering enn andre kvinner. Karlsen (2012b, s.129) viser at dette er tilfelle blant norske kvinner. Hun finner at kvinnelige ingeniører er klart mer likestillingsorienterte enn kvinnelige sykepleiere. Det er viktig å ha dette funnet som et bakteppe, når en vurderer ulike forklaringer på kjønnsforskjeller i forventninger om lederstillinger og faktisk representasjon i lederstillinger blant ingeniører.

\section{Tilbuds- og etterspørselsforklaringer}

To ulike sett av forklaringer har blitt lansert på kvinners underrepresentasjon i lederstillinger, nemlig tilbuds- og etterspørselsforklaringer (Reskin, 1993). Etterspørselsforklaringer er en samlebetegnelse på forklaringer som hevder at menn og kvinner forskjellsbehandles i arbeidslivet. Denne forskjellsbehandlingen kan romme alt fra intendert til uintendert diskriminering eller handle om strukturer i arbeidslivet som favoriserer menn.

Når det gjelder etterspørselsforklaringen slår en metastudie fast at det i analyser av store datasett ikke har blitt funnet systematiske bevis for favorisering av menn (Bygren et al., 2017, s. 337). Forskerne har gått gjennom mange studier basert på sosiale eksperiment som ser på arbeidsgiveres avgjørelse om å ta kontakt med jobbsøkere med identiske kvalifikasjoner, men forskjellig kjønn. De finner ingen tendens til at arbeidsgiverne viser en preferanse for menn. 
Studiene sier imidlertid ikke noe om hva som skjer når stillinger ikke utlyses, men rekrutteringen skjer gjennom nettverk. Rekruttering gjennom uformelle nettverk kan åpne for favorisering av menn, ettersom menn ofte har flest menn i eget nettverk. I privat sektor hvor de fleste ingeniører arbeider blir stillinger ofte ikke utlyst og ansettelsesprosessen kan ha en uformell karakter (Hansen, 1997). Dette kan selvsagt være et problem for kvinnelige ingeniører.

I denne artikkelen skal vi i hovedsak ta for oss den såkalte tilbudsforklaringen, som retter lyset mot kvinnene selv og deres livsbetingelser utenfor arbeidslivet. Det innebærer ikke at vi utelukker etterspørselsforklaringer, det vil si ulike former for diskriminering. Det er mulig å tenke seg at både tilbuds- og etterspørselsforklaringer virker samtidig, eller at bare en av dem skaper en effekt. I analysen skiller vi mellom følgende fire typer tilbudsforklaringer; motivasjon, omsorgsforpliktelser, selvtillit og forventninger om diskriminering.

\section{TILBUDSFORKLARING 1: MOTIVASJON}

En variant av denne forklaringstypen tar utgangspunkt i at menn og kvinner er ulike, enten dette skyldes sosialisering eller biologi (eller begge). Menn og kvinner antas å ha ulike verdier og preferanser som igjen gir seg utslag i ulike ambisjoner. Noen teoretikere knytter disse forskjellene til sosialisering tidlig i livet (Chodorow, 1978; Hakim, 2002). Andre mener at forskjellene oppstår senere, og fremhever kvinnelige erfaringer som moderskapet og underordning (Cockburn, 1991). I tråd med dette finner Colbjørnsen og Knudsen (2018) at kvinner starter lederkarrieren på et lavere nivå og har en kortere arbeidstid enn menn i samme jobb. De forklarer denne forskjellen med at kvinnelige ledere i høyere grad enn mannlige ledere velger å tilpasse sitt karriereløp etter barnas omsorgsbehov. Senere i karrieren, når omsorgsbehovet avtar, tar kvinner igjen noe av det forspranget som menn har skaffet seg, viser Colbjørnsen og Knudsens analyser.

Healy og Heavans (1987) beskriver den tradisjonelle kvinnelige sosialisering som antitesen til lederskap, slik dette konvensjonelt forstås. Sett i dette perspektivet blir det forståelig om kvinner ikke finner seg til rette i organisasjoner preget av menns verdier, og at de rett og slett ikke ønsker å bli ledere. I en norsk studie av sivilingeniører hevder Kvande og Rasmussen (1990, s. 155) at kvinner har bedre karrieremuligheter i små virksomheter enn i store 
byråkratiske organisasjoner. Denne konklusjonen har imidlertid blitt tilbakevist av andre empiriske studier (Powell \& Butterfield, 1997; Storvik \& Schøne, 2008).

At kvinner ikke ønsker å bli ledere er en forklaring som får liten empirisk støtte. De fleste undersøkelser viser at menn og kvinner i like høy grad ønsker å bli ledere og toppledere (Andreassen \& Folkenborg, 2002; Storvik \& Schøne, 2008). Mye tyder på at dette også gjelder kvinner og menn med profesjonsutdanning. Blant annet finner Fekjær og Halrynjo (2012) ingen forskjeller i kvinners og menns фnske om en lederkarriere blant første års politistudenter. Mannlige og kvinnelige ingeniører er svært enige om at jobb er en svært viktig del av livet og noe de ville drevet med selv om de ikke hadde behøvd det av $\emptyset$ konomiske grunner (Karlsen, 2012b, s. 132). Sett på bakgrunn av disse funnene kan det antas at kjønn ikke har betydning for karriereambisjoner.

\section{TILBUDSFORKLARING 2: OMSORGSFORPLIKTELSER}

En annen variant av forklaringstypen viser til kvinners og menns ulike muligheter og livsbetingelser. Et eksempel på en slik forklaring finner vi hos Acker (1992). Hun peker på at en implisitt forutsetning for å være leder er en ektefelle som tar hovedansvaret for familien. I vårt samfunn er det som regel kvinner som tildeles denne oppgaven, og av den grunn vil kvinner ikke ha de samme karrieremuligheter som menn. Ellingsæter og Pedersen (2013) peker på at noen kvinner i høyere middelklasseyrker av denne grunn utsetter å få barn. Dette kan gjelde kvinner som ser for seg en lederkarriere. Højgaard (2002) hevder at ekteskapsmønsteret bidrar til ulike muligheter for mannlige og kvinnelige ledere. Hun viser at mannlige næringslivsledere ofte er gift med en partner som arbeider deltid og tar hovedansvaret hjemme. Kvinnelige ledere, innenfor alle sektorer, er i motsetning til dette som oftest gift med en partner som har like lang arbeidstid som de selv. Halrynjo og Lyng (2010) finner at det også blant foreldrepar med høy og lik utdanning, samme yrke og samme ambisjoner, er det en tendens til at kvinner reduserer sin innsats på jobben når de får barn. Menn, derimot, øker sin innsats i arbeidslivet etter at de har blitt fedre. Kjønnslikhet i aspirasjoner om en lederkarriere finner Fekjær og Halrynjo (2012) også blant første års studenter ved politiskolen. Familiestatus har ingen betydning verken for menns eller kvinners $\emptyset$ nsker om en lederkarriere. Fekjær og Halrynjo mener at en forklaring på like aspirasjoner blant kvinnelige og mannlige politistudenter kan være liten erfaring med å kombinere familie og arbeid. Karlsen (2012b, s. 133) finner at kun $21 \%$ av mannlige ingeniører og $11 \%$ av 
kvinnelige ingeniører mener at mannen bør være hovedforsørger mens kvinnene bør bidra noe. Analysen viser at det store flertallet ønsker en likedeling av forsørgeransvaret. Sett på denne bakgrunn forventer vi ikke at barn har en annen betydning for menn enn for kvinners holdninger til fremtidig karriere.

\section{TILbUdSFORKLARING 3: SELVTILlit}

At kvinner mangler selvtillit har også blitt brukt som en forklaring på hvorfor det er færre kvinner enn menn som blir ledere. Forskning har vist at når kvinner skal vurdere egne ferdigheter innenfor fag og oppgaver som konvensjonelt blir forstått som menns domener, har de en tendens til å undervurdere egne prestasjoner (Ridgeway \& Correll, 2004). Correll (2001) finner at når studenter skal vurdere egne kunnskaper i matematikk så vurderer kvinnene egne ferdigheter lavere enn hva menn gjør. Denne forskjellen opprettholdes også om vi sammenligner menn og kvinner som på tester har vist det samme evnenivået. Bandura (1997) introduserte begrepet "self-efficacy" som viser til troen en person har på at han eller hun har de personlige egenskaper og ressurser som skal til for å løse en spesiell oppgave. I følge Bandura vil denne mestringstroen ha betydning for hvilke karrieremål en person forfølger og for om hun eller han lykkes med å nå sine mål. Her vil vi for enkelhets skyld kalle denne mestringstroen for selvtillit, og vi ser for oss at denne kan variere i forhold til ulike typer oppgaver. I en metastudie av selvtillit kom det frem at kvinner hadde lavere selvtillit enn menn innenfor mannstypiske fag som matematikk, men høyere innenfor språklige- og estetiske fag (Huang, 2013). Videre fant McCormick et al. (2002) at menn hadde mer selvtillit til egne lederegenskaper enn kvinner. Slike studier kan være viktig for å forstå hvorfor menn og kvinner velger ulike karrierer og for å forstå hvorfor de kan oppvise ulik grad av selvtillit (Ridgeway \& Correll, 2004, s. 526). Det som synes å være tilfellet er at kjønnede undertekster knyttet til fag og arbeidsoppgaver påvirker kvinners vurdering av egne prestasjoner og evner. Orupabo (2013) finner også slike eksempler i en kvalitativ studie blant bachelorstudenter på IT-ingeniørutdanningen i Norge. Mens noen av kvinnene synes å undervurdere egne ferdigheter synes noen av mennene å overvurdere seg selv, sammenlignet med faktiske karakterer på studiet. Innenfor et såpass mannsdominert område som ingeniørfag kan en derfor forvente at kvinner har en tendens til å undervurdere egne ferdigheter. 
Surveyen vi benytter i denne studien har ikke opplysninger om studentenes faglige selvtillit eller mestringstro (self-efficacy). I analysen bruker vi derfor studentenes 'forventinger om å ta mastergrad' som indikasjon på faglig selvtillit.

\section{TILBUDSFORKLARING 4: FORVENTET DISKRIMINERING}

En ikke så vanlig forklaring på kjønnsforskjeller i lederansvar er forventninger om kjønnsdiskriminering (McWhirter 1997, s.125). Forventninger om diskriminering kan føre til at kvinner opptrer annerledes enn menn, f.eks. ved å la være å søke lederstillinger eller i mindre grad opptre som uformelle ledere i arbeidssituasjonen. En del nyere forskning har pekt på betydningen av forventninger for videre karriereutvikling. Brody (1995) fant at ansatte i en salgsavdeling som trodde de skulle rykke opp, oftere gjorde dette enn sine mindre optimistiske kolleger. Perrone et al. (2010) fant at begavede studenter ofte fikk oppfylt sine karriereforventinger. Tilsvarende fant Abrahamsen og Storvik (2016) en klar positiv sammenheng mellom studenters ambisjoner og lederansvar senere i karrieren.

Tidligere forskning viser at kvinner opplever mer diskriminering på arbeidsplassen enn menn (Gutek et al., 1996). McWhirter (1997) viser at tenåringer i USA som er underutdanning forventer kjønnsdiskriminering $\mathrm{i}$ arbeidslivet og at det er flest kvinner som tror de vil bli utsatt for dette. Norske studier av Rønning og Karlsen (2014) og Halrynjo et al. (2015) viser at både menn og kvinner mener at kvinner diskrimineres ved lederansettelser, men det er flest kvinner som tror dette. Storvik og Schøne (2008) mener at forventninger om diskriminering kan være grunnen til at kvinner sjeldnere enn menn søker lederstillinger i staten. Både menn og kvinner ønsker i like høy grad å klatre i lederhierarkiet. Når kvinner og menn oppfordres av arbeidsgiver til å søke en lederstilling, søker kvinner like ofte som menn. Når en slik oppfordring ikke foreligger, søker menn klart oftere. Storvik og Schøne forklarer dette med en antakelse om diskriminering og viser til tidligere studier som finner at blant ansatte i staten er det mange som tror at dette foregår.

Harris et al. (2004) hevder at forventninger om diskriminering forekommer hyppigst hvis arbeidsgivere/ledere tilhørere en historisk dominant gruppe, slik som menn, og hvis kandidatene tilhørere en historisk sett underordnet gruppe slik som kvinner. Dette innebærer at antagelser om diskriminering vil være mest utbredt i profesjoner hvor mange ledere er menn, slik som ingeniøryrket, og i mindre grad i yrker med mange kvinnelige leder slik som sykepleier. Harris et al. hevder også at trekk ved rekrutteringsprosessen vil påvirke inntrykket 
av diskriminering. En formalisert prosess vil resultere i mindre mistanke om diskriminering. Det innebærer at ansettelsesprosesser i privat sektor, som ofte er mer uformelle, vil være mer usatt for mistanke enn ansettelsesprosesser i offentlig sektor, hvor det ofte kreves utlysning. Gorman (2015, s. 134) argumenterer også for at kvinner er mer interessert i jobber i organisasjoner hvor det enten nå eller tidligere har vært en del kvinner i lederposisjoner, fordi de tror at deres sjanser for opprykk vil være større her.

Mange av jobbene som ingeniører orienterer seg mot befinner seg i organisasjoner med få kvinnelige arbeidsgivere/ledere og har mindre formaliserte utlysningsprosesser. Derfor vil forventningene om diskriminering være særlig utbredt i denne delen av arbeidsmarkedet.

Vi spør ikke kvinner og menn direkte om deres forventninger om kjønnsdiskriminering. I stedet spør vi om de forventer å ha en lederstilling ti år frem i tid. Vi argumenterer for at kjønnsforskjeller i forventninger om lederstillinger kan reflekterer antagelser om diskriminering. Gitt at menn og kvinner er like når det gjelder ambisjoner, faglig selvtillit og at barn ikke har betydning (i tillegg til bachelorprogram og alder), er det sannsynlig at forventninger om diskriminering ligger bak en slik kjønnsforskjell.

\section{Forskningsspørsmål og begreper}

I litteraturen er det vanlig å bruke individers $\emptyset$ nsker og forventinger om hverandre. Vi mener det bør skilles mellom disse begrepene og at et slikt skille kan bidra til å forstå personers karrierebeslutninger og barrierene som påvirker disse beslutningene. Mens ambisjoner antas å bli utviklet relativt tidlig i denne prosessen og er et utrykk for personens innerste $\varnothing$ nske for en fremtidig karriere, kan karriereforventninger antas å være mer relatert til karrierebeslutningen. Forventinger kan sies å være ønsker som har gjennomgått en realitetsvurdering. I følge Johnson (1995) er forventinger mål som den enkelte ser som realistiske og oppnåelige.

Vi skal her undersøke to forskningsspørsmål:

(1) Har kvinnelige og mannlige ingeniørstudenter like ambisjoner?

(2) Forventer mannlige og kvinnelige ingeniørstudenter i samme grad å bli ledere? 


\section{Data, variabler og metode}

Analysen er basert på StudData, en norsk panelundersøkelse som omfatter studenter fra vel 20 profesjonsstudier (bachelor) fra flere utdanningsinstitusjoner. Dataene i denne studien omfatter studenter i ulike ingeniørfag som fullførte utdanningen våren 2007. Artikkelen omfatter 375 ingeniørstudenter, 306 menn og 69 kvinner. Alle studentene innenfor ingeniørfag (på utvalgte utdanningsinstitusjoner) fikk utlevert et spørreskjema i siste studiesemester. Til sammen 54 prosent svarte på skjemaet.

\section{Avhengige variabler}

Variabelen 'Karriereambisjoner' er sammensatt av to jobb-verdier. Studentene besvarte følgende spørsmål: 1) Hvor viktig er muligheter for avansement når du vurderer en fremtidig jobb? 2) Hvor viktig er høy lønn når du vurderer en fremtidig jobb? Fem svaralternativer ble gitt (skala 1-5) hvor 1 er 'ikke viktig i det hele tatt', og 5 er 'svært viktig'.

Variablene 'Forventninger til fullført mastergrad' og 'Forventinger til lederansvar' er basert på følgende spørsmål: Hvis du prøver å forestille deg livet om 10 år, hvor sannsynlig er det at følgende utsagn vil passe for deg? 1) 'Jeg har fullført mastergrad'. 2) 'Jeg har lederansvar'. Svarene gis på en 5-punkts skala hvor 1 er 'Svært viktig' og 5 er 'Ikke viktig i det hele tatt'. I analysene er skalaen for begge variablene snudd.

\section{Uavhengige variabler}

Kjønn er kodet 0 for 'Kvinner' og 1 for 'Menn'. Variabelen 'Barn' er kodet 0 for 'Ingen barn' og 1 for 'Har et eller flere barn'. Alder er inndelt i 4 kategorier, hvor 1 er 'Under 24 år, 2 er '24-28 år', 3 er '29-33 år' og 4 er '33 år eller mer'.

\section{Statistisk metode}

I tillegg til å estimere gjennomsnitt og prosentandeler (Tabell 1), benyttes lineære regresjonsmodeller (OLS) i analysen av karriereambisjoner, forventninger om mastergrad og forventninger om lederansvar (Tabell 2). 


\section{Resultater}

\section{Deskriptive resultater}

Tabell 1 viser deskriptive resultater for kvinnelige og mannlige ingeniørstudenter i sitt siste studiesemester. Resultatene viser studentenes karriereambisjoner og fremtidige forventninger om mastergrad og lederansvar. Analysene viser at kvinner og menn har like høye karriereambisjoner (4,02 for kvinner og 3,96 for menn), men at menn har signifikant høyere forventninger om lederposisjon enn kvinner (3,36 for kvinner og 3,73 for menn). Videre har kvinnelige studenter signifikant høyere forventninger om mastergrad enn mannlige studenter (3,33 for kvinner og 2,81 for menn).

Av tabell 1 går det også frem at mannlige og kvinnelige ingeniørstudenter har tilnærmet lik gjennomsnittsalder (25,5 år og 26 år). Videre er det like utbredt blant begge kjønn å ha barn (7 prosent). 
Tabell 1

Deskriptive resultater: gjennomsnitt og standardavvik. Ingeniørstudenter siste studiesemester

\begin{tabular}{|c|c|c|c|}
\hline & Kvinner & Menn & Signifikans \\
\hline $\begin{array}{l}\text { Karriereambisjoner } \\
\text { M (SD) }\end{array}$ & $4,02(0,53)$ & $3,96(0,60)$ & i.s. \\
\hline $\begin{array}{l}\text { Forventninger om } \\
\text { mastergrad } 10 \text { år etter } \\
\text { utdanning } \\
M(S D)\end{array}$ & $3,33(1,44)$ & $2,81(1,44)$ & $*$ \\
\hline $\begin{array}{l}\text { Forventninger om } \\
\text { lederposisjon } 10 \text { år etter } \\
\text { utdanning } \\
M(\text { SD) }\end{array}$ & $3,36(1,17)$ & $3,73(0,97)$ & * \\
\hline Har barn, \% & 7 & 7 & i.s. \\
\hline $\begin{array}{l}\text { Alder } \\
\text { M (SD) }\end{array}$ & $25,5(3,32)$ & $26,0(4,03)$ & i.s. \\
\hline $\mathrm{N}$ & 69 & 306 & \\
\hline
\end{tabular}

i.s.: ikke signifikant, ${ }^{*} \mathrm{p}<0.05$

\section{Regresjonsanalyser}

Tabell 2 viser resultatene fra lineære regresjonsanalyser (OLS) av studentenes karriereambisjoner (Modell 1) og deres forventninger om mastergrad (Modell 2) og forventninger om lederansvar (Modell 3). Studentenes karriereambisjoner, forventninger om mastergrad og lederansvar er basert på en skala from 1-5 (1= veldig lave, 5=veldig høye). Analysene inkluderer flere uavhengige variabler: kjønn, alder og barn. Det er også gjennomført analyser med samspillsleddet kjønn*barn, men ingen signifikante samspillsledd ble funnet og ble derfor tatt ut av analysene. Det er heller ikke forskjeller i karakter mellom menn og kvinner (analyse ikke vist). 
Tabell 2

Lineær regresjonsanalyse av karriereambisjoner (1-5), forventninger mastergrad (1-5) og forventninger om lederansvar (1-5). Ingeniører. $\beta$-verdier med standardfeil (SE) i parentes

\section{Karriereambisjoner $\begin{gathered}\text { Forventninger } \\ \text { Mastergrad }\end{gathered} \quad \begin{gathered}\text { Forventninger } \\ \text { Lederansvar }\end{gathered}$}

$\begin{array}{lcc}\text { Model 1 } & \text { Model 2 } & \text { Model 3 } \\ \beta(\text { SE) } & \beta(S E) & \beta(S E)\end{array}$

\section{Kjønn}

Ref.gr.: kvinner

$$
-0,05(0,08) \quad-0,42 *(0,19) \quad 0,40 * *(0,13)
$$
Alder
$-0,11 * *(0,04)$
$-0,30 * *(0,11)$
$0,17 *(0,07)$

\section{Har barn}

Ref.gr.: uten barn

$$
0,18(0,13) \quad-0,45(0,32) \quad-0,06(0,22)
$$

\section{Karriereambisjoner}

\section{Konstant}

Justert R2

$\mathbf{N}$

$* \mathrm{p}<0.05, * * \mathrm{p}<0.01$

$$
0,38 * *(0,12) \quad 0,59 * *(0,08)
$$

$$
4,29 * *(0,16) \quad 2,79 * *(0,67) \quad 0,24(0,46)
$$

0,013

0,078

0,131

360

Resultatene i tabell 2 viser at kvinnelige ingeniører har like høye karriereambisjoner som sine mannlige studiekollegaer (Modell 1) også når det kontrolleres for alder og barn. Derimot er det signifikante kjønnsforskjeller i karriereforventninger (kontrollert for alder, kjønn og ambisjoner). Kvinner har høyere forventninger om mastergrad enn menn (-0,42), men lavere forventninger om lederansvar $(0,40)$. Som forventet er det en klar positiv sammenheng mellom studentenes karriereambisjoner og deres forventninger om mastergrad $(0,38)$ og 
lederansvar (0,59). Det er heller ikke forskjeller i karakter mellom menn og kvinner og karakterer kan derfor ikke forklare kjønnsforskjellen i forventningen om mastergrad.

Videre viser analysene at alder har en negativ signifikant effekt på ingeniørstudentenes karriereambisjoner $(-0,11)$ og forventinger om mastergrad $(-0,30)$. Derimot er det en positiv sammenheng (signifikant) sammenheng mellom alder og forventninger om lederansvar $(0,17)$. Det å ha barn har ingen signifikant betydning for verken ingeniørstudentenes ambisjoner eller karriereforventninger.

\section{Diskusjon}

Resultatene viser at kvinnelige ingeniørstudenter har like høye karriereambisjoner som mannlige ingeniørstudenter. Det vil si at begge kjønn legger like stor vekt på mulighetene for avansement og høy lønn når de vurderer en fremtidig jobb. Videre har kvinner høyere forventninger om mastergrad, men lavere forventninger om lederansvar enn menn.

De kvinnelige ingeniørstudentene er altså like ambisiøse som sine mannlige medstudenter. Med andre ord synes kvinner i alle fall ikke å være mindre interesserte i karriere og lønn slik den første forklaringstype (1) hevdet. Resultatene i vår studie er ikke i tråd med den tidligere teoretiske litteraturen (Becker, 1985; Hakim, 2002), men sammenfaller med flere empiriske studier, både norske (Halrynjo \& Lyng, 2010; Abrahamsen \& Drange, 2015) og amerikanske studier (Rowe \& Snizek, 1995; Marini et al., 1996).

Den andre forklaringen (2) hevdet at familieforpliktelser er et større problem for kvinner enn for menn. Ingeniørstudentene i vår undersøkelse er i siste halvdel av tyveårene og de fleste har ikke barn. Resultatene viser at omsorg for barn ikke påvirker ingeniørstudenter verken med hensyn til karriereambisjoner eller karriereforventninger. Tidligere forskning tyder på at barn har ulik betydning for kvinners og menns yrkeskarriere, hvor fedre kommer bedre ut enn mødre (Mandel \& Semyonov, 2006; Gangl \& Ziefle, 2009). Vår studie sier ingenting om hvorledes barn faktisk påvirker menn og kvinners karriere, bare noe om hvorledes barn påvirker ingeniørstudentenes ambisjoner og forventninger.

Den tredje forklaringen (3) hevder at kvinner har mindre faglig selvtillit enn menn. Tidligere studier har som nevnt vist at dette kan være tilfellet innenfor mannstypiske fagområder som 
ingeniørstudiene (Correll, 2001; Huang, 2013; Orupabo, 2013). Studentenes forventninger om å ha fullført en mastergrad innen en ti års tid kan sees som et tegn på akademisk selvtillit, gitt like ambisjoner. I følge Bandura (1997, s. 432) påvirkes egen mestringstro i arbeidslivet av rollemodeller, det vil si personer som en kan identifisere seg med og som har lykkes. Personer en identifiserer seg med tilhører ofte det en oppfatter som ens egen gruppe, og kvinner vil ofte identifisere seg med andre kvinner. Ettersom det er relativt få kvinnelige ingeniører og enda færre kvinnelige ingeniører som er ledere (Karlsen 2012b, s. 157), skulle en forvente at dette har konsekvenser for kvinners og menns mestringstro. En skulle forvente at kvinnelige studenter sammenlignet med mannlige, har mindre forventninger både om at de skal ta mastergrad og at de skal bli ledere. Vi finner derimot at kvinnelige ingeniørstudenter faktisk har signifikant høyere forventninger om å ha fullført en mastergrad innen en tiårs tid. Hvis vi kontrollerer for flere uavhengige variabler som alder, barn og ambisjoner består denne sammenhengen. Det er heller ikke forskjeller i karakter mellom menn og kvinner. Karakterer kan derfor ikke forklare kjønnsforskjellen i forventningen om mastergrad. Disse resultatene gjør at vi kan konkludere med at kvinner har minst like mye faglig selvtillit som menn. Dette funnet avviker fra tidligere nevnte empiriske studier og teori på feltet (Ridgeway $\&$ Corell, 2014) og er et interessant funn. En sterk maskulin undertekst som preger dette faget (Cockburn, 1991) synes altså ikke å påvirke disse kvinnenes akademiske egenvurdering. Derimot kan den maskuline underteksten forklare at få kvinner velger denne studieretningen. Imidlertid er det mulig at kvinner har lavere selvtillit når det gjelder personlig egnethet for lederstillinger. Hvis ledelse har en maskulin undertekst (Kanter, 1977), kan det føre til at kvinner i mindre grad enn menn ser seg selv som egnet for lederstillinger. I dag er dette mindre sannsynlig fordi et mer kjønnsbalansert ledelsesideal er utbredt (Fondas, 1997; Solberg, 2012; Storvik, 2012) og gjør dette mindre sannsynlig (McCormic et al., 2002). I en amerikansk studie fant man også at kvinnelige studenter hadde et mer kjønnsbalansert ledelsesideal enn mannlige studenter (Schein, 2007, s. 11). Hvis vi i tillegg går utfra at kvinner i mannsdominerte yrker er blant de mest likestillingsorienterte (Bandura, 1997, s. 129; Karlsen, 2012b, s. 129), er det trolig at kvinnene på ingeniørstudiet i like høy grad som sine mannlige medstudenter ser seg selv som kompetente for lederstillinger.

Diskusjonen så langt viser at resultatene i vår studie verken gir støtte til forklaringer knyttet til kvinnenes motivasjon (1), omsorgsforpliktelser (2) eller selvtillit (3). Derimot er det mye 
som tyder på at studien støtter opp om forklaring (4): forventinger om diskriminering. Vårt utgangspunkt er at forventninger om diskriminering kan ha samme effekt som faktisk diskriminering. Dette skyldes at forventningene påvirker atferd (Bandura, 1997). Frykt for kjønnsdiskriminering ved lederansettelser kan få kvinner til i mindre grad å vise uformell lederadferd på arbeidsplassen. Videre kan forventningene også føre til at kvinner i mindre grad enn menn søker lederstillinger, slik Storvik og Schøne (2008) mener er tilfelle i det norske statsbyråkratiet. Forventinger om diskriminering kan også påvirke hvor en søker seg jobb, om en velger offentlig fremfor privat virksomhet og om en velger store firmaer fremfor små (Orupabo, 2013).

McWhirter (1997) finner at tenåringer under utdanning i USA har forventninger om kjønnsdiskriminering $\mathrm{i}$ arbeidslivet. Tidligere norske studier har vist at mange tror at kvinner som $\varnothing$ nsker lederstillinger møter spesielle barrierer i arbeidslivet (Storvik, 2012; Rønning \& Karlsen, 2014; Halrynjo et al., 2015). Forventninger om kjønnsdiskriminering er altså utbredt også i det norske arbeidslivet. Det er nettopp slike forventninger som kan forklare at kvinnelige ingeniørstudenter i mindre grad enn sine mannlige medstudenter ser for seg å ende opp i en lederstilling. I og med at vår studie viser at mannlige og kvinnelige studenter har like ambisjoner, like høy faglig selvtillit og at barn ikke har betydning, er dette en sannsynlig forklaring.

Harris et al. (2004) mener at forventninger om diskriminering vil være mest fremtredende når de fleste arbeidsgivere (ledere) er menn og når rekrutteringsprosessen er uformell. Dette vil ofte være tilfellet i privat sektor og det er derfor her en kan forvente de størst kjønnsforskjellene i forventninger om lederstillinger. En studie av bachelorstudenter viser da også et slikt resultat (Storvik \& Abrahamsen, under publisering). Forventningene om diskriminering synes å være høyere blant kvinner på ingeniør- og IT utdanningene, hvor hoveddelen av arbeidsmarkedet ligger i privat sektor, sammenlignet med kvinner som utdanner seg innenfor velferdsprofesjoner.

Forventninger i begynnelsen av karrieren er viktige fordi tidligere forskning viser at kjønnsforskjeller i stillingsnivå ofte oppstår tidlig i karrieren (Barth et al., 2005; Bihagen \& Ohls, 2006; Zeng, 2011; Albrecht et al., 2015). Zeng (2011) fant i en amerikansk studie at kvinnelige ingeniører og forskere ikke steg like raskt i gradene som sine mannlige kolleger og 
at denne forskjellen var størst i første del av karrieren. Dette funnet tyder på at det viktig å studere startfasen av karrieren mer inngående.

Forventinger om diskriminering kan endre seg over tid. Endringer i kvinneandel innenfor et yrke og stilling vil sannsynligvis påvirke forventninger. Blant ingeniører utgjør kvinnene i 2017 fremdeles bare 15\% (Bufdir, 2018). Når det gjelder ledere, har kvinneandelen økt noe de ti årene som er gått siden studien ble gjennomført, og det kan gjøre at dagens kvinnelige studenter har noe høyere forventninger om lederstillinger. Kvinnelige ledere innenfor ingeniøryrket vil imidlertid fremdeles utgjøre en svært liten andel, og dette er trolig med på å holde kvinnelige studenters forventninger om å bli ledere nede.

Forventninger om diskriminering reflekterer både faktisk diskriminering og forestilt diskriminering i samfunnet. I tillegg til å unngå faktisk diskriminering, er det også viktig å bekjempe forestilt diskriminering. For å bekjempe feilaktige forventninger er det især to ting virksomheter kan gjøre. Å ha flere kvinnelige ledere vil gi et signal til kvinner om at det er mulig for kvinner å gjøre karriere i virksomheten, slik Gorman (2015) peker på. Videre vil utlysning av stillinger og en formalisert ansettelsesprosess også ha samme virkning, slik Harris (2004) argumenterer for. Likeledes kan kvinner i ansettelsesutvalgene også bidra til å skape et inntrykk av en rettferdig ansettelsesprosess.

\section{Referanser}

Abrahamsen, B. \& Storvik, A. (2016). Lederutvelgelse blant profesjonsutøvere. I E. Døving, B. Elstad \& A. Storvik (red.), Profesjon og ledelse. Bergen: Fagbokforlaget.

Abrahamsen, B. \& Drange, I. (2015). Ethnic Minority Students' Career Expectations in Prospective Professions: Navigating between Ambitions and Discrimination. Sociology, 49(2), 252-269. DOI: https://doi.org.10.1177/0038038514542494

Acker, J. (1992). Gendering Organisational Theory. I A. Mills \& P. Tancred (red), Gendering Organisational Analysis. London: Sage.

Albrecht, J., Thoursie, P. S. \& Vroman, S. (2015). Parental Leave and the Glass Ceiling in Sweden. Working Paper No 2015:4. Uppsala: Institute for Evaluation of Labour 
Market and Education Policy. DOI: https://doi.org/10.1108/S0147$\underline{912120140000041010}$

Amdam, R. P. \& Kvålshaugen, R. (2016). Ledelse som profesjon i Norge - Fagkompetanse versus ledelseskompetanse. I E. Døving, B. Elstad \& A. Storvik (red), Profesjon og ledelse: Bergen: Fagbokforlaget.

Andreassen, J. \& Folkenborg, K. (2002). Vi vil! Slipp oss til! Oslo: Fafo. https://www.fafo.no/media/com_netsukii/381.pdf

Arnesen, C. A., Støren, L. A. \& Wierss-Jenssen, J. (2015). Teknologer, realister og økonomer på arbeidsmarkedet. Kandidatundersøkelsen tre år etter fullført utdanning blant teknologer, realister og økonomer. Oslo: NIFU. https://brage.bibsys.no/xmlui/bitstream/handle/11250/2357670/NIFUrapport201530_rev.pdf? sequence $=4$

Bandura, A. (1997). Self-efficacy: The exercise of control. New York: H. W. Freeman and Company.

Barth, E., Røed, M. \& Schøne, P. (2005). Lønnsforskjeller mellom kvinner og menn i privat sektor: betydningen av yrke og virksomhet. Søkelys på arbeidsmarkedet, 22(2), 211216.

Becker, G. (1985). Human Capital, Effort, and the Sexual Division of Labor, Journal of Labor Economics, 3(1), 33-58. DOI: https://doi.org.10.1086/298075

Bihagen, E. \& Ohls, M. (2006). The Glass ceiling - Where is it? Women's and Men's Career Prospects in the Private vs. the Public Sector in Sweden 1979-2000. The Sociological Review, 54(1), 20-47. DOI: https://doi.org.10.1111/j.1467-954X.2006.00600.x

Briody, E. K., Baba, M. L. \& Cooper, L. (1995). A Tale of Two Career Paths: The Process of Status Acquisition by a New Organizational Unit. Work and Occupations, 22, 301327. DOI: https://doi.org/10.1177/0730888495022003004

Bufdir (2018, 23. august). Sektorer, næringer og yrker: kjønnsfordeling. Hentet fra https://www.bufdir.no/Statistikk_og_analyse/Kjonnslikestilling/Arbeidsliv_og_kjonn/ Kjonnsfordeling_sektorer/ 
Bygren, M., Erlandsson, A. \& Gähler, M. (2017). Do Employers Prefer Fathers? Evidence from a Field Experiment Testing the Gender by Parenthood Effect on Callbacks to Job Applications, European Sociological Review, 33(3), 337-346. DOI: https://doi.org.10.1093/esr/jcx051

Chodorow, N. (1978). The Reproduction of Mothering: Psychoanalysis and the Sociology of Gender. Berkeley CA: University of California Press.

Cockburn, C. (1991). In the Way of Women. London: Macmillan.

Colbjørnsen, T. \& Knudsen, K. (2018) Underveis. Menns og kvinners lederkarrierer. Tidsskrift for samfunnsforskning, 59(2), 131-156. DOI: https://doi.org.10.18261/ISSN.1504-291X-2018-02-01

Correll, S. J. (2001). Gender and the Career Choice Process: The Role of Biased SelfAssessments. American Journal of Sociology, 106(6), 1691-1730. DOI: https://doi.org.10.1086/321299

Ellingsæter, A. L. \& Pedersen, E. (2013). Fruktbarhetens fundament i den norske velferdsstaten. Tidsskrift for samfunnsforskning, 54(1), 3-29. https://www.idunn.no/tfs/2013/01/fruktbarhetens_fundament_idennorske_velferdsstat en

Fekjær, S. B. \& Halrynjo, S. (2012). Promotion aspirations among male and female police students. International Journal of Police Science and Management, 14(1), 71-82. DOI: https://doi.org.10.1350/ijps.2012.14.1.262

Fondas, N. (1997). Feminization Unveiled: Management Qualities in Contemporary Writings. Academy of Management Review, 22(1), 257-87. DOI: https://doi.org.10.5465/AMR.1997.9707180266

Hakim, C. (2002). Lifestyle Preferences as Determinants of Women's Differentiated Labour Market Careers. Work and Occupation, 4(29), 428-459. DOI: https://doi.org.10.1177/0730888402029004003

Halrynjo, S., Kitterød, R. H. \& Teigen, M. (2015). Hvorfor så få kvinner på toppen i Norsk Næringsliv? - En analyse av hva topplederne selv sier. Søkelys på Arbeidslivet, 31(1- 
2), 111-136. https://www.idunn.no/spa/2015/01-

02/hvorfor_saa_faa_kvinner_paa_toppen_i_norsk_naeringsliv_-_en_an

Halrynjo, S. \& Lyng, S. T. (2010). Fars forkjørsrett - mors vikeplikt? Karrierer, kjønn og omsorgsansvar i eliteprofesjoner. Tidsskrift for Samfunnsforskning, 2, 249-280. https://www.idunn.no/tfs/2010/02/art04

Hansen, M. N. (1997). Sosiale nettverk, rekrutteringskanaler og lønn i det norske arbeidsmarkedet. Tidsskrift for samfunnsforskning, 2, 175-195.

Harris, M., Lievens, F. \& Van Hoye, G.V. (2004). 'I Think They Discriminated Against Me': Using Prototype Theory and Organizational Justice Theory and Organizational Justice Theory for Understanding Perceived Discrimination in Selection and Promotion Situations'. International Journal of Selection and Assessment, 12(1-2), 54-65. DOI: https://doi.org.10.1111/j.0965-075X.2004.00263.x

Healy, L. M. \& Havens, C. M. (1987). Feminist Leadership Styles as a Force for Humanizing the Workplace. Paper for the Third International Interdisciplinary Congress of Women, Dublin, 6-10 July.

Huang, C. (2013). Gender Differences in Academic Self-Efficacy: a Metaanalysis. European Journal of Psychology of Education, 28(1), 1-35. DOI: https://doi.org.10.1007/s10212-011-0097-y

Højgaard, L. (2002). Tracing Differentiation in Gendered Leadership. An Analysis of Differences in Gender Composition in Top Management Business, Politics and the Social Services. Gender, Work and Organisation, 9(1), 15-39. DOI: https://doi.org.10.1111/1468-0432.00147

Johnson, L. (1995). A multidimensional analysis of vocational aspirations of college students. Measurement and Evaluation, 28(1), 25-44. https://www.researchgate.net/publication/234612641_A_Multidimensional_Analysis of_the_Vocational_Aspirations_of_College_Students

Gangl, M. \& Ziefle, A. (2009). Motherhood, labor force behavior, and women's careers: An empirical assessment of the wage penalty for motherhood in britain, germany and the united states. Demography, 46(2), 341-369. DOI: https://doi.org/10.1353/dem.0.0056 
Gorman, E. H. (2015). Getting ahead in professional organizations: individual qualities, socioeconomic background and organizational context. Journal of Professions and Organization, 2(2), 122-147. DOI: https://doi.org.10.1093/jpo/jov001

Gutek, B. A., Cohen, A. G. \& Tsui, A. (1996). Reactions to Perceived Sex Discrimination. Human Relations, 49(6), 791-813. DOI: https://doi.org.10.1177/001872679604900604

Kanter, R.B. (1977). Men and Women of the Corporation. New York: Basic Books.

Karlsen, H. (2012a). Gender and ethnic differences in occupational positions and earnings among nurses and engineers in Norway. Identical choices, unequal outcomes. Work, Employment and Society, 26(2), 278-295. DOI: https://doi.org.10.1177/0950017011432907

Karlsen, H. (2012b). Not so unconventional after all? A Quantitative study of men in careoriented study programmes and professional occupations in Norway (Doktorgradsavhandling). Oslo: Høgskolen i Oslo og Akershus.

Kvande, E. \& Rasmussen, B. (1990). Nye kvinneliv. Kvinner i menns organisasjoner. Oslo: AdNotam.

Marini, M., Fan, P. L., Finley,E. \& Beutel, A.M. (1996). Gender and Job Values. Sociology of Education, 69(1), 49-65. DOI: https://doi.org/10.2307/2112723

Mandel, H. \& Semyonov, M. (2006). A Welfare Stat Paradox: State interventions and women's employment opportunities in 22 countries. American Journal of Sociology, 111(6), 1910-1949. DOI: https://doi.org.10.1086/499912

McCormic, M.J., Tanguma, J. \& Lopez-Forment, A.S. (2002). Extending Self-Efficacy Theory to Leadership. A Review and Empirical Test. Journal of Leadership Education, 1(2), 34-49. http://journalofleadershiped.org/attachments/article/23/JOLE_1_2_McCormick_Tang uma_Lopez-Forment.pdf

McWhirter, E.H. (1997). Perceived Barriers to Education and Career: Ethnic and Gender Differences. Journal of Vocational Behaviour, 50, 124-140. DOI: https://doi.org.10.1006/jvbe.1995.1536 
Orupabo, J. (2013). Kompetanse- en symbolsk markør. Kjønn, etnisitet og aspirasjoner i overgangen mellom utdanning og arbeidsmarked (Doktorgradsavhandling). Oslo: Universitetet i Oslo. https://www.duo.uio.no/handle/10852/39116

Perrone, K. M., Tschopp, M. K., Snyder, E. R., Boo, J. N. \& Hyatt, C. (2010). A Longitudinal Examination of Career Expectations and Outcomes of Academically Talented Students 10 and 20 Years Post-High School Graduation. Journal of Career Development, 36(4), 291-305. DOI: https://doi.org.10.1177/0894845309359347

Powell, G. \& Butterfield, D. (1997). Effects of Race and Gender on Promotions to Top Management in a Federal Department. Academy of Management Journal, 40, 112128. DOI: $\underline{\text { https://doi.org/10.5465/257022 }}$

Reskin, B. (1993). Sex Segregation in the Work-Place. Annual Review of Sociology, 19, 241-270. DOI: https://doi.org/10.1146/annurev.so.19.080193.001325

Ridgeway, C.L. \& Correll, S.J. (2004). Unpacking the gender system. A Theoretical Perspective on Gender Beliefs and Social Relations. Gender and Society, 18(4), 510531. DOI: https://doi.org.10.1177/0891243204265269

Rowe, R. \& Snizek, W.A. (1995). Gender differences in work values: perpetuating the myth. Work and Occupation, 22, 215-229. DOI: https://doi.org/10.1177/0730888495022002005

Rønning, R. \& Karlsen, B. (2014). Kjønnsbalanse i seks norske selskaper. Hovedrapport fra forskningsprosjektet Gender Balance. Bergen: AFF Norges Handelshøyskole.

Sappleton, N \& Takruri-Rizk, H. (2008). The Gender Subtext of Science, Engineering and Technology (SET) organizations: A Review and Critique. Women's Studies, 37(3), 284-316. DOI: https://doi.org.10.1080/00497870801917242

Schein, V. E. (2007). Women in management: reflections and projections. Women in management Review, 22(1), 6-18. DOI: https://doi.org.10.1108/09649420710726193

Solberg, A.G. (2012). Et kjønnsperspektiv på innovasjonsledelse (Doktorgradsavhandling). Oslo: Universitetet i Oslo. DOI: https://doi.org/10.1177/0730888495022002005 
SSB (2017, 30. desember). 6 av 10 høyere utdanninger fullføres av kvinner. Hentet fra http://www.ssb.no/utdanning/artikler-og-publikasjoner/6-av-10-hoyere-utdanningerfullfores-av-kvinner

Storvik, A. \& Schøne, P. (2008). In search of the glass ceiling: gender and recruitment to management in Norway's state bureaucracy. British Journal of Sociology, 59(4), 729755. DOI: https://doi.org.10.1111/j.1468-4446.2008.00217.x

Storvik, A. (2012). Introducing the Feminist Management Discourse in Organizations. Review of European Studies, 4(1), 155-166. DOI: https://doi.org.10.5539/res.v4n1p155

Storvik, A. \& Abrahamsen, B. (in press). Gender Gap in Management in Early Career: The Role of an Anticipated Glass Ceiling.

U.S. Glass Ceiling Commission (1995). Good for Business: Making Full Use of the Nation's Human Capital. Washington D. C.: Department of Labour.

Utdanning (2018, 23. august). Kjemiingeniør. Hentet fra https://utdanning.no/statistikk/nus/395861/kjonn

Zeng, Z. (2011). The myth of the glass ceiling: Evidence from a stock-flow analysis of authority attainment. Social Science Research, 40(1), 312-325. DOI:

https://doi.org.10.1016/j.ssresearch.2010.06.012

\section{Om forfatterne:}

Aagoth Elise Storvik er dr. polit. i sosiologi og professor ved Handelshøyskolen, OsloMet Storbyuniversitetet. Hun forsker blant annet på kjønn og ledelse, rekruttering til lederstillinger og styrer, profesjon og organisasjon.

Bente Abrahamsen er dr. polit. i sosiologi og professor ved Senter for profesjonsstudier, OsloMet - Storbyuniversitetet. Hun forsker på rekruttering, motivasjon og karrierer i profesjoner. 